\title{
Peningkatan pengetahuan masyarakat tentang akibat pernikahan dini dari aspek kesehatan, hukum dan pendidikan di Desa Pulau Jambu Kecamatan Kuok Kabupaten Kampar
}

\author{
Wan Nishfa Dewi*, Hayatul Ismi, Ihda Hasbiyati, Maimunah, Ulfia Hasanah, Mukhlis Ridwan, dan \\ Deviona
}

Universitas Riau

*wan.dewi@lecturer.unri.ac.id

\begin{abstract}
Abstrak. Masyarakat Desa Pulau Jambu, Kecamatan Kuok, Kabupaten Kampar memiliki kecenderungan untuk melakukan pernikahan dibawah umur. Hal ini berdasarkan hasil penelitian yang dilakukan pada tahun 2017. Pernikahan yang dilakukan diusia dini akan menimbulkan masalah baik dari aspek kesehatan, hukum dan pendidikan. Tujuan pelaksanaan kegiatan pengabdian masyarakat ini adalah untuk memberikan informasi dan peningkatan pengetahuan masyarakat Desa Pulau Jambu akibat pernikahan dini dari aspek kesehatan, hukum dan pendidikan keluarga. Kegiatan pengabdian masyarakat yang dilakukan adalah berupa identifikasi kearifan lokal masyarakat, identifikasi sumber daya masyarakat desa, penyuluhan terkait pernikahan dini meliputi aspek hukum, kesehatan reproduksi, kesehatan remaja dan dampak tidak langsung akibat pernikahan dini. Hasil pengabdian ini menunjukkan bahwa masyarakat sebagaian besar memahami hal-hal yang terkait dengan permasalahan akibat pernikahan dini. Tim bina desa keluarga sejahtera juga telah terbentuk setelah tim pengabdian dan aparat desa melakukan musyarawarah.
\end{abstract}

Kata kunci: pengetahuan masyarakat; hukum; kesehatan reproduksi; pendidikan keluarga; pernikahan dini

Abstract. People in Pulau Jambu Village, Kuok district, Kampar Regency have a significant number of early marriage. Several consequences emerge related to early marriage from the perspective of law, reproduction health and family education. This community service aimed to provide sufficient information as well as to improve community understanding of early marriage impacts from the perspectives of law, health and education through counselling. Activities involved in community services are ranged from the identification of local wisdom, identification of human resources, early marriage counselling from perspective of law, teenage health, reproduction health, and other direct impacts on early marriage. This community service anticipates improving people in Pulau Jambu village capacity to have a better life and to provide proper solutions related to issues emerging in the community. The result of this community services found that the majority of people in Pulau Jambu Village understand the moderate level of impacts of early marriage after attending counselling and lecture related to early marriage and its problems. Collaboration team between people of Pulau Jambu, village officials, and Universitas Riau have been formed.

Keywords: community understanding; law; reproduction health; family education; early marriage

\footnotetext{
To cite this article: Dewi, W. N., H. Ismi, I. Hasbiyati, Maimunah, U. Hasanah, M. Ridwan, \& Deviona. 2019. Peningkatan pengetahuan masyarakat tentang akibat pernikahan dini dari aspek kesehatan, hukum dan pendidikan di Desa Pulau Jambu Kecamatan Kuok Kabupaten Kampar. Unri Conference Series: Community Engagement 1: 383-387 https://doi.org/10.31258/unricsce.1.383-387
}

(C) 2019 Authors

Peer-review under responsibility of the organizing committee of Seminar Nasional Pemberdayaan Masyarakat 2019 


\section{PENDAHULUAN}

Perkawinan merupakan jenjang awal pembentukan masyarakat, dari suatu parkawinan akan terbentuk masyarakat kecil yang bernama rumah tangga. Di dalamnya akan lahir seorang anak atau lebih. Dalam kelompok individu tersebut lahir organisasi sosial yang bernama keluarga dan membentuk relasi-relasi seperti hubungan suami istri, anak dan orang tua, anak dengan saudara-saudaranya, anak dengan kakek-neneknya, anak dengan paman dan tantenya, ayah-ibu dengan saudara dan ipar-iparnya, suami istri dengan orang tua dan mertuanya, dan seterusnya. Remaja sebagai anak yang ada pada masa peralihan dari masa anak-anak menuju usia dewasa pada masa peralihan ini biasanya terjadi percepatan pertumbuhan dari segi fisik maupun psikis. Baik ditinjau dari bentuk badan, sikap, cara berpikir dan bertindak mereka bukan lagi anak-anak. Mereka juga belum dikatakan manusia dewasa yang memiliki kematangan pikiran. Sifat-sifat keremajaan ini (seperti emosi yang tidak stabil, belum mempunyai kemampuan yang matang untuk menyelesaikan konflik-konflik yang dihadapi, serta belum memepunyai pemikiran yang matang tentang masa depan yang baik), akan sangat mempengaruhi perkembangan psikososial anak dalam hal ini kemampuan konflik pun, usia itu berpengaruh. Dari keterangan di atas dapat disimpulkan bahwa kedewasaan ibu baik secara fisik maupun mental sangat penting, karena hal itu akan berpengaruh terhadap perkembangan anak kelak dikemudian hari. Oleh itulah maka sangat penting untuk memperhatikan umur pada anak yang akan menikah.

Pada kenyataannya didalam masyarakat perkawinan usia muda ada dilaksanakan, terutama didalam masyarakat pedesaan atau masyarakat berpendidikan rendah. Perkawinan ini dilakukan dengan alasan kesulitan ekonomi, serta kebiasaan adat yang terjadi pada keluarga yang malu mempunyai anak gadis hamil diluar nikah atau terlalu intim dengan pasangan yang belum sah secara agama dan tidak sesuai dengan normanorma di suatu daerah.

Pernikahan usia muda juga membawa pengaruh yang tidak baik bagi anak-anak mereka. Biasanya anakanak kurang kecerdasannya. Anak-anak yang dilahirkan oleh ibu-ibu remaja mempunyai tingkat kecerdasan yang lebih rendah bila dibandingkan dengan anak yang dilahirkan oleh ibu-ibu yang lebih dewasa. Mengenai pembatasan umur untuk melaksanakan perkawinan ini dimaksudkan sebagai pencegahan terhadap perkawinan yang masih di bawah umur. Akan tetapi pada kenyataannya perkawinan yang masih di bawah umur itu masih sering terjadi ditengah-tengah masyarakat kita, khususnya yang terjadi Propinsi Riau (Wijaya, 2013).

\section{MASALAH}

Salah satu daerah yang juga menjadi perhatian bagi penulis adalah Desa Pulau Jambu Kecamatan Kuok Kabupaten Kampar. Berdasarkan hasil penelitian yang dilakukan pada tahun 2017 oleh Yuliana Citra, diketahui bahwa masyarakat desa Pulau Jambu memiliki kecenderungan untuk melakukan pernikahan dibawah umur (Yuliana, 2017).

Di Desa Pulau Jambu Kecamatan Kuok memiliki 3103 jiwa penduduk dengan 839 KK. Saat ini ditemukan adanya orangtua yang menikahkan anak-anak perempuan yang baru saja menyelesaikan sekolah menengah pertama (SMP). Bukan hanya orangtua yang andil dalam memutuskan untuk menikahkan anak perempuan mereka yang baru saja tamatan SMP atau berusia 14-15 tahun, namun anak-anak perempuan di Desa Pulau Jambu yang berusia 14-15 tahun juga tidak keberatan untuk menikah diusia dini tersebut. Angka pernikahan usia dini akan terus melonjak disebabkan karena faktor ekonomi dan pergaulan. Dari sisi ekonomi, orangtua tidak sanggup lagi menghidupi kebutuhan anak dikarenakan penghasilan yang serba kekurangan. Penghasilan orangtua diketahui berkisar Rp 800.000-Rp 1.500.000/bulan dan mata pencarian penduduk Desa Pulau Jambu mayoritas sebagai Petani baik itu petani karet ataupun petani kelapa sawit. Sedangkan karena faktor pergaulan disebabkan karena anak itu sendiri yang memutuskan untuk menikah dan tidak melanjutkan sekolahnya.

Pernikahan usia dini di Desa Pulau Jambu sudah berlangsung sangat lama secara turun temurun. Masyarakat Desa Pulau Jambu tidak menolak adanya Perubahan sosial yang terjadi didalam masyarakat tersebut seperti banyaknya kaum perempuan yang ingin melanjutkan pendidikan. Malah akan didukung oleh masyarakat Desa Pulau Jambu lainnya jika ada keputusan tersebut. Namun yang menjadi permasalahan adalah anak-anak perempuan di Desa Pulau Jambu tidak mau melanjutkan pendidikan dan memilih untuk menikah di usia yang sangat muda dan belia. Titik permasalahan lainnya adalah orangtua tidak melarang anak-anak perempuan untuk menikah muda dan bahkan memberikan dukungan materi dan moril. Keputusan masyarakat untuk menikahkan anak perempuan mereka di usia muda di Desa Pulau Jambu adalah karena pengaruh agama Islam yang kuat dan ketaatan penduduk yang sangat kental akan agama. Diperoleh informasi yang didapatkan dari ketua RT dan tokoh adat Desa Pulau Jambu diketahui bahwa anak-anak perempuan yang masih duduk dibangku SMP ada yang melakukan hubungan seks diluar pernikahan. 
Penuturan kepala desa Pulau Jambu Bapak M. Rayan terkait permasalahan yang bersangkutan: "Setiap bulan hampir belasan anak-anak pelajar SMP yang kami amankan saat tertangkap berhubungan badan sedangkan statusnya belum menikah. Yang lebih disayangkan lagi, tidak ada perbedaan umur yang jauh diantara keduanya. Masih sama-sama pelajar SMP.

Perkawinan di bawah umur merupakan perkawinan yang terjadi di mana pihak pria atau wanita yang belum mencapai umur yang sudah disyaratkan dalam Undang-undang yang berlaku, yaitu bila pihak pria sudah mencapai umur 19 tahun dan pihak wanita sudah mencapai umur 16 tahun. Oleh karena itu, perkawinan pria yang sudah akil baligh dengan wanita yang belum baligh dapat dinilai tidak sah. Perkawinan yang dilakukan dibawah umur biasanya tidak dicatatka.

Perkawinan yang tak dicatatkan juga bukan tanpa resiko. Yang mengalami kerugian utama adalah pihak istri dan anak-anak yang dilahirkannya. Karena, apabila ia tak memiliki dokumen pernikahannya, seperti surat nikah, maka ia akan kesulitan mengklaim hak-haknya selaku istri terkait dengan masalah perceraian, kewarisan, tunjangan keluarga, dan lain-lain (Hukum Online, 2019). Tentu ini akan menimbulkan permasalahan di bidang hukum.

Jika melihat kepada data-data di atas, ada pengaruh/dampak negatif yang ditimbulkan dari perkawinan di bawah umur, yaitu:

1. Secara psikologi hal tersebut tentunya berpengaruh pada kondisi mental yang masih labil serta belum adanya kedewasaan dari si anak. Dikhawatirkan, keputusan yang diambil untuk menikah adalah keputusan remaja yang jiwa dan kondisi psikologisnya belum stabil. Jadi, keputusannya bukan orang dewasa yang belum menyadari bahwa menikah adalah suatu keputusan besar dimana akan menimbulkan hak dan kewajiban dalam perkawinan yang dijalaninya.

2. Pernikahan di usia belia berbahaya bagi kesehatan. Apalagi perempuanlah yang cukup banyak memiliki risiko seperti pada kandungan dan kebidanannya. Sebab, secara medis menikah di usia tersebut dapat mengubah sel normal (sel yang biasa tumbuh pada anak-anak) menjadi sel ganas yang akhirnya dapat menyebabkan infeksi kandungan dan kanker. Sedangkan untuk kebidanan, hamil di bawah usia 19 tahun tentunya sangat beresiko pada kematian. Terlebih secara fisik remaja belum kuat yang pada akhirnya bisa membahayakan proses persalinan.

Ilmu kesehatan memandang baik secara kesempurnaan dan psikologi, umur yang ideal untuk menikah, bagi laki-laki 25 tahun dan perempuan 20 tahun. Tetapi masih banyak yang tidak memperdulikan hal tersebut, bukan hanya di Desa Pulau Jambu tetapi di Indonesia masih banyak daerah yang melakukan hal tersebut.

\section{METODE}

Kegiatan penyuluhan ini merupakan salah satu cara untuk meningkatkan pengetahuan dan kesadaran masyarakat tentang akibat Perkawinan dibawah umur dari segi hukum dan kesehatan. Kepada masyarakat juga diberikan penyuluhan tentang penting pendidikan sehingga masyarakat akan menyadari dan memahami pentingnya pendidikan bagi anak karena pendidikan ini juga merupakan hak dari anak. Kegiatan ini juga dilakukan untuk meningkatkan kesadaran hukum masyarakat tentang akibat baik dari segi kesehatan, hukum dan pendidikan. Diharapkan juga permasalahan-permasalahan yang terjadi berpangkal dari pernikahan dibawah umur dapat diminimalisir.

Program ini adalah program kemitraan perguruan tinggi dengan masyarakat yang terdiri dari kegiatan tri darma perguruan tinggi berupa implementasi pembelajaran di bidang kesehatan, hukum dan pendidikan, melalui proses identifikasi masalah dan solusinya melalui penelitian dan pengabdian masyarakat. Terbentuknya tim bina keluarga sejahtera berbasis masyarakat merupakan salah satu langkah sumbangsih yang bisa diberikan Universitas Riau sebagai apresiasi kesediaan masyarakat untuk menjalankan program kemitraan ini.

Demikian tujuan pelaksanaan kegiatan pengabdian masyarakat ini secara khusus adalah meliputi:

1. Meningkatkan kompetensi masyarakat (pengetahuan, keterampilan, motivasi dan peran dengan pembentukan tim bina desa keluarga sejahtera)

2. Melalukan pendampingan dan pembinaan kepada masyarakat dalam mengantisipasi terjadinya perkawinan dibawah umur bagi remaja-remaja potensial untuk melangsungkan perkawinan. 


\section{PEMBAHASAN}

Sosialisasi dan penyuluhan dilakukan pada beberapa kelompok masyarakat. Diawali oleh kelompok masyarakat sebagai orang tua, anggota Posyandu dan PKK di desa Pulau Jambu Kecamatatan Kuok. Kegiatan ini mendapatkan respon yang positif. Dari warga masyarakat. Kegiatan dilaksanakan di kantor Pasyandu di Desa pulau Jambu kecamantan Kampar. Kegiatan ini dilaksanakan pada tanggal 19 juli 2019, acara dimulai pada pukul $15.00 \mathrm{Wib}$. Acara ini diikuti oleh 70 (Tujuh puluh) orang peserta. Kepala Desa dalam acara ini sekaligus sebagai pembuka acara. Hadir juga Sekretaris Desa, Kepala Dusun serta tokoh-tokoh masyarakat lainnya. Peserta sosialisasi sangat antusias untuk mengikuti acara ini karena mereka menyadari bahwa bekal pengetahuan yang meraka dapatkan nantinya akan bermanfaat untuk meningkatkan pengetahuan mereka di bidang hukum, kesehatan dan pendidikan. Penyuluhan juga dilakukan pada remaja yang sedang atau tidak menempuh pendidikan. Diharapkan kedua kelompok sasaran ini dapat berkontribusi agar dapat menurunkan tingkat pernikahan dini.

Acara penyuluhan dimulai dengan sambutan dari Kepala Desa Pulau Jambu, Kecamatan Kuok, kemudian sambutan serta perkenalan dari Tim Pengabdian Bina Desa, yang diwakili oleh Keta Pengabdian dari Universitas Riau. Setelah itu dilanjutkan dengan presentasi tentang Pernikahan dibawah umur dan implikasinya terkait kesehatan, pendidikan dan pendidikan. Dalam penyuluhan ini dijelaskan tentang Peraturan Perundang-undangan yang mengatur Tentang Pernikahan, dan syarat-syarat pernikahan serta Akibat Hukum dari pernikahan yang dilakukan dibawah umur. Penyampaian Materi didahului dengan Pemutaran Video terkait Pelaku yang melakukan pernikahan dibawah umur. Selanjutnya pada akhir materi, diberikan kesempatan kepada peserta Sosialisasi untuk diskusi dimana para peserta bebas bertanya tentang Syarat-syarat yang harus dipenuhi jika seseorang menikah, sebab-sebab terjadi pernikahan dibawah umur, serta akibatakibatnya dari bidang hukum, kesehatan dan pendidikan.

Setelah kegiatan sosialisasi ini dilakukan, kegiatan selanjutnya adalah pembentukan tim bina desa keluarga sejahtera. Kepada tim bina desa ini diberikan program kerja (dalam bentuk pelatihan/ workshop) terkait: Bina Kesehatan, Bina Hukum dan pembinaan di bidang yang dibutuhkan oleh masyarakat. Diharapkan dengan dibentuknya tim bina desa ini akan memberikan pendampingan kepada masyarakat dan memberikan pengetahuan tentang akibat dari pernikahan dini dari segi hukum, kesehatan, ekonomi dan pedidikan.
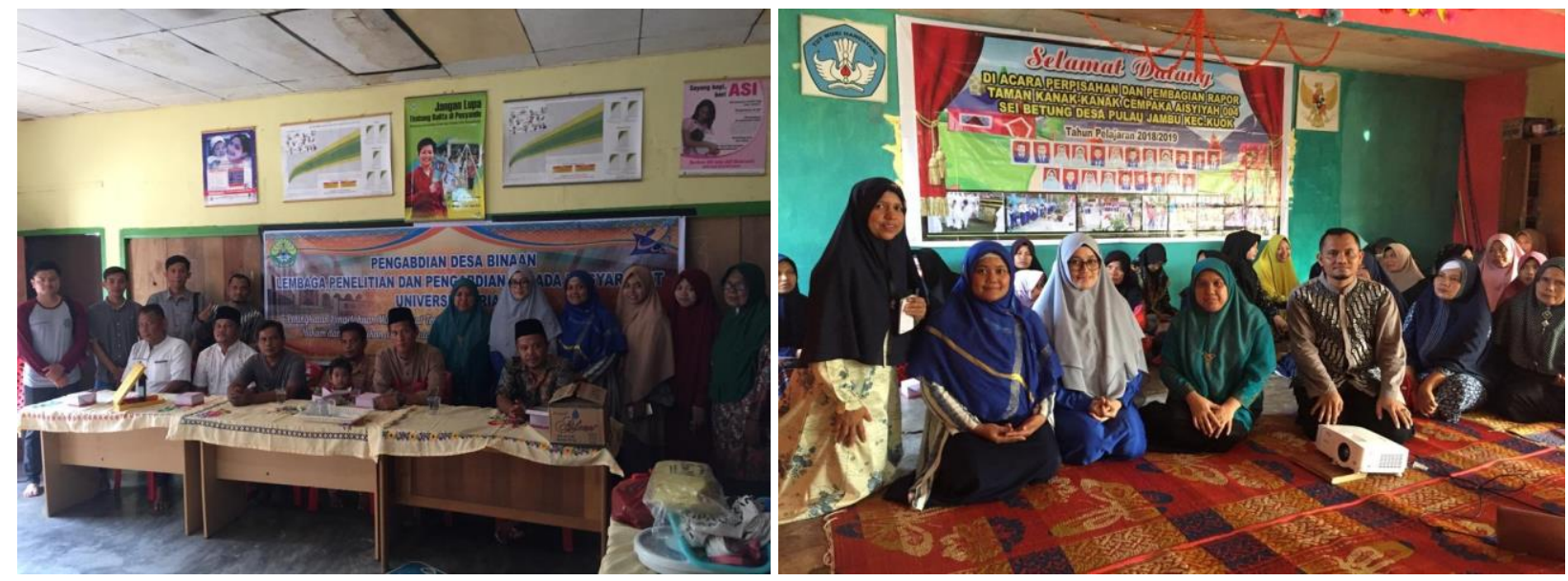

Gambar 1. Penyuluhan oleh Peserta Pengabdi

\section{KESIMPULAN}

Hasil kegiatan pengabdian bina desa ini menunjukkan bahwa masih banyak masyarakat yang belum memahami dampak dari pernikahan dini dari semua sisi kehidupan masyarakat dan keluarga. Oleh karena itu perlu pembinaan secara berkesinambungan dan melalui kegiatan bina desa ini diharapkan mampu meningkatkan pemahaman masyarakat dan merubah paradigm yang sudah turun temurun terjadi di desa pulau jambu ini. 


\section{DAFTAR PUSTAKA}

Ediastuti, E., dan Manikam, I. H. 2010. Determinan Remaja Melakukan Hubungan Seks Pranikah. Dalam Keluarga Berencana dan Kesehatan Reproduksi. Diedit oleh Tukiran, A.J. Pitoyo, Pande Made Kutanegara. Yogyakarta: Pustaka Pelajar dan Pusat Studi Kependudukan dan Kebijakan.

Intruksi Presiden Nomor 1 Tahun 1991 tentang Kompilasi Hukum Islam (KHI).

Peraturan Pemerintah No. 9 tahun 1975 tentang pelaksanaan Undang-Undang No. 1 tahun 1974.

Saleh, K. W. 2004. Syarat-Syarat Perkawinan Menurut Para Ahli Hukum. Jakarta: PT. Bumi Aksara.

Sarwono, S. W. 1987. Seksualitas dan Fertilitas Remaja. Jakarta: Rajawali bekerja sama dengan Perkumpulan Keluarga Berencana Indonesia.

Susetyo, H. 2009. Perkawinan Di Bawah Umur Tantangan Legislasi dan Harmonisasi Hukum Islam. Jakarta: PT. Bumi Aksara.

Undang-Undang Nomor 1 Tahun 1974 tentang perkawinan.

Undang-undang Nomor 35 Tahun 2014 Tentang Perlindungan Anak.

Undang-Undang Nomor 36 Tahun 2009 Tentang Kesehatan.

Wijaya, A. A. 2013. Analisis akibat hukum perkawinan dibawah umur tinjauan dari Hukum Islam dan UU No.1 Tahun 1974 Tentang Perkawinan. Skripsi, Mataram.

Yuliana, C. 2017. Pernikahan usia Dini pada Perempuan di Desa Pulau Jambu Kecamatan Kuok Kabupaten Kampar. FISIP, Universitas Riau.

Yusuf, S. 2001. Psikologi Perkembangan Anak dan Remaja. Bandung: Remaja Rosdakarya. 